\title{
PHYSIOLOGICAL ROLES AND ASSOCIATED DISORDERS OF ADIPONECTIN
}

\author{
SHAILAZA SHRESTHA ${ }^{1}$, PREETI SHARMA²*, PRADEEP KUMAR ${ }^{2}$, SAXENA SP ${ }^{1}$, RACHNA SHARMA ${ }^{3}$
}

${ }^{1}$ Department of Biochemistry, Hind Institute of Medical Sciences, Ataria, Sitapur, Uttar Pradesh, India. ${ }^{2}$ Department of Biochemistry, Santosh Medical College \& Hospital (Santosh University), Ghaziabad, Uttar Pradesh, India. ${ }^{3}$ Department of Biochemistry, TSM Medical College and Hospital, Lucknow, Uttar Pradesh, India. Email: prcdri2003@yahoo.co.in

Received: 28 August 2016, Revised and Accepted: 27 September 2016

\section{ABSTRACT}

Among the adipokines, adiponectin is the first one to be described just over a decade ago. It is produced exclusively by adipose tissue and circulates in high concentration in human plasma accounting for $0.01 \%$ of proteins in plasma, almost thousand times higher than that of leptin. The normal circulating level of adiponectin ranges from 2 to $30 \mu \mathrm{g} / \mathrm{ml}$. It is now observed that besides adipose tissue, adiponectin can also be produced by several other tissues such as hepatocytes, cardiomyocytes, and placenta. Adiponectin executes its action via autocrine as well as and paracrine effects. Researchers working in this area have revealed that adiponectin has insulin-sensitizing, anti-inflammatory and cardioprotective effects. Our review focuses on adiponectin, its mode of action on different peripheral tissues such as skeletal muscles, heart, liver, brain and its the correlative account in various diseases.

Keywords: Adiponectin, Obesity, Type 2 diabetes, Inflammation, Malignancies, Cardiovascular disease.

(C) 2017 The Authors. Published by Innovare Academic Sciences Pvt Ltd. This is an open access article under the CC BY license (http://creativecommons. org/licenses/by/4. 0/) DOI: http://dx.doi.org/10.22159/ajpcr.2017.v10i1.14928

\section{INTRODUCTION}

Adiponectin, chief adipokine of adipocytes [1] is a $30 \mathrm{kDa}$ secretory protein made up of 244 amino acids [2] coded by APM1 gene located on chromosome 3q27 [3]. Not only adipocytes but some other cells such as cardiomyocytes, hepatocytes, and placenta also have the ability to produce adiponectin in small quantity [2]. It is denoted by various terms such as AdipoQ [4], the other ones being gelatin-binding protein-28 [5] and adipocyte complement-related protein of $30 \mathrm{kDa}$ [6] Domains present are namely: A C-terminal globular domain, a collagenlike domain, and an N-terminal domain [3]. Three homooligomeric forms of adiponectin namely trimeric form, hexameric form, and high molecular weight multimeric form (HMW) have been identified in humans [7]. HMW being most active form [8] and the collagenous domain being important for the oligomerization [9]. G-protein coupled receptors commonly known as adiponectin receptors, viz., adipo R1, adipo R2, and T-cadherin modulate the action of adiponectin in various tissues. [10]. Major receptor in skeletal muscle is adipo R1, whereas that in the liver and vascular endothelial cells is adipo R2 and T-cadherin, respectively [11].

\section{ACTION OF ADIPONECTIN ON VARIOUS TISSUES AND ORGANS}

As a hormone, adiponectin exhibits autocrine and paracrine action in adipose tissue, whereas endocrine activity in distal ones [12].

\section{Adipose tissue}

In adipocytes, it regulates cellular differentiation, suppresses inflammatory markers such as interleukins (IL6 and 8), inflammatory, and chemotactic proteins production, thus inhibiting lipid storage and enhancing insulin sensitivity [13].

\section{Skeletal muscles}

Earlier, adiponectin was thought to produce its metabolic effects on skeletal muscle via endocrine activity [14]. However, according to recent studies, myocytes are also capable of secreting adiponectin that can exert local effects and hence, it may be regarded as a myokine [15].

Adiponectin has an insulin sensitizing effect on skeletal muscle [9] that is achieved by lowering muscular lipid levels [16]. It causes glucose utilization [17], uptake of fatty acids and oxidation [18], lowers ceramide levels [19] and stimulates mitochondrial biosynthesis [18] These actions are brought about by stimulation of adenosine monophosphate kinase (AMPK), peroxisome proliferator activator receptor $\alpha$ (PPAR $\alpha$ ), and p38 mitogen-activated protein kinase [17]. AMPK translocates glucose transporter Type 4 transporters to cell membrane [20] and regulates glucose utilization and $\beta$ oxidation, whereas PPAR $\alpha$ regulates lipid metabolism by controlling the expression of genes involved [21]. AMPK renders acetyl-CoA carboxylase (ACC) inactive via phosphorylation and decreases levels of malonyl-CoA [22], a molecule that allosterically inhibits carnitine palmitoyl transferase 1 , which is the enzyme required for fatty acid transport to mitochondria for oxidation [23]. Fatty acids in muscles are derived from triglyceride hydrolysis caused by lipoprotein lipase [24] that is activated by adiponectin [25].

Stefan et al. showed a positive association of adiponectin with insulinmediated glucose utilization and decreased insulin sensitivity with lower adiponectin levels [26]. In a cohort follow-up study, Teros et al. stated that older age individuals with hyperinsulinemia possess a high risk of skeletal muscle wasting [27]. Ceramide has been recently identified as a new factor impairing muscle insulin sensitivity [28]. Adiponectin via activation of ceramidase lowers myocellular ceramide level and enhances insulin sensitivity as well as mitochondrial biosynthesis [19].

Both animal [21] and human studies [29] have confirmed the stimulatory role of adiponectin on mitochondrial biosynthesis and its oxidative capacity. These effects are mediated via activated AMPK [30]. In addition, a strong correlation exists between adiponectin levels and mitochondrial DNA content in human skeletal muscle [29].

\section{Cardiovascular system}

Adiponectin is considered as cardioprotective adipokine [31] because it not only prevents vascular remodeling by suppressing tumor necrosis factor $\alpha$ (TNF- $\alpha$ ) [32] and platelet-derived growth factor [32] but also possesses effective antiatherogenic [33], anti-inflammatory [34], and antithrombotic effects [35]. These protective actions are provided via the activation of AMPK [36] and cyclooxygenase 2 [37]. 
Adiponectin prevents monocyte attachment to endothelium [38] and nuclear factor-kappa beta (NF- $\mathrm{k} \beta$ ) signaling, suppressing the expression of cell adhesion molecule and IL-8, a proinflammatory cytokine [38]. All these effects contribute to the anti-inflammatory role. Further, as an antiatherogenic agent, it is able to prevent the formation of foam cells. On one hand, it reduces the expression of receptors for Class A scavenger [39], whereas, on another hand, it depresses acyl-CoA cholesterol acyltransferase enzyme responsible for the synthesis of cholesteryl esters [39]. As per Kumada et al., adiponectin upregulates IL-10, stabilizes atheromatous plaque [40], and also inhibits thrombus formation [41].

Adiponectin as an antioxidant protects the vasculature from oxidative stress via augmentation of endothelial nitric oxide synthase (eNOS) synthesis [42]. This enzyme is activated by phosphorylation, thereby increasing the production of NO [43]. Furthermore, adiponectin also suppresses superoxide formation and stimulates eNOS interaction with heat shock protein 90 that allows eNOS to render its function at maximum level [44].

Adiponectin also regulates fatty acid oxidation and glucose transport via mechanism similar to skeletal muscle and thus maintains hydraulic work of cardiomyocytes, therefore, increasing cardiac efficiency [45].

\section{Liver}

Adiponectin exerts its effect in the liver via activation of AMPK, $\operatorname{PPAR} \alpha[12]$ pathways, and sterol regulatory element-binding protein 1c (SREBP) [46]. First, AMPK inactivates ACC by phosphorylation; second, it reduces levels of malonyl-CoA, and third, it increases oxidation of fatty acids by favoring its transport to mitochondria [47]. In addition, PPAR $\alpha$ stimulates fatty acid oxidizing enzymes [46] and SREBP 1c, also known as a transcription factor, downregulates the lipogenic genes [48].

Adiponectin also exerts antifibrotic through suppression of profibrotic factor [49] induced hepatic stellate cells transformation to myofibroblast [50]. Adiponectin as an anti-inflammatory agent in liver mediates its role by inhibiting TNF- $\alpha$ [51] and activating tolllike receptor-4 [52]. However, mechanism involved is still unclear and requires further researches.

\section{Lungs}

Receptors for adiponectin, especially adipo R1 [53], are expressed in pulmonary epithelium suggesting lung to be one of the target organs of adiponectin [54]. Thyagarajan et al. demonstrated a positive relation among lung function and adiponectin [55]. In vitro studies on mice model elucidated the protective role of adiponectin against inflammation [56] and post-ischemic lung injury [57]. As per Summer et al., adiponectin inhibits the action of alveolar macrophages and maintains vascular homeostasis [58].

\section{Kidney}

Kidney possesses plenty of perirenal fat [59] and expresses adipo $\mathrm{R} 1[60]$ that on activation by AMPK regulates renal synthetic activities and protects glomerulus from oxidative stress. According to Fang et al., angiotensin causes activation of nicotinamide adenine dinucleotide phosphate (NADH) oxidase and results in oxidative stress, but these effects are attenuated by adiponectin [61]. Adiponectin activates caspase-8 and preserves podocytes of glomerulus from apoptosis [62] It also upregulates nephrine, a podocyte-derived protein, and decreases of which contributes to proteinuria [63]. Adiponectin is mainly cleared from the body via liver but kidneys also contribute to some extent [64]. Thus, urinary adiponectin, only monomeric and dimeric isoforms, can be traced in small quantity [65] as they can cross glomerular barrier [66].

\section{Brain}

The role of adiponectin in brain and actual mechanism involved is poorly elucidated. Although some researches are published in this regard, conflicting results are obtained. According to some authors, cerebrospinal fluid lacks adiponectin as the brain cells are incapable of secreting adiponectin, but they do express its receptors [67]. In contrast, recent studies have shown local expression of adiponectin in the cells of pituitary gland suggesting that adiponectin may locally regulate systemic metabolism through the central nervous system [68]. Adiponectin may be also regarded as a starvation gene as there is an increase in adiponectin levels in the arcuate hypothalamus during fasting state, and this effect may lead to increased hypothalamic AMPK activity promoting food intake [69].

\section{ASSOCIATION OF ADIPONECTIN IN VARIOUS PATHOLOGICAL CONDITIONS}

The serum concentration of circulating adiponectin ranges from 2 to $30 \mu \mathrm{g} / \mathrm{ml}$ which accounts for $0.01 \%$ of proteins present in plasma [70]. The level of adiponectin is approximately $40 \%$ higher in females as compared to males [71]. First, plausible reason for this may be inhibition of adiponectin secretion by androgens [9] and second may be genderbased differential in body fat distribution [72]. Because adiponectin affects number of tissues and organs, it has been implicated in various pathological states.

\section{Obesity and adiponectin}

Obesity, a condition of increased total body fat mass [73], determined by anthropometric indices such as body mass index (BMI) [74], waist-hip ratio [75] correlate negatively with adiponectin [76] which may be due to transcriptional suppression of adiponectin by inflammatory cytokines [77], but obese person when reduce their weight [78] leads to increase in adiponectin level suggesting reversibility of obesity-associated hypoadiponectinemia [79]. Hoffstedt et al. reported lower adiponectin mRNA in obese person [80]. Adiponectin gene polymorphism at $276 \mathrm{G}>\mathrm{T}$ is linked with obesity and related complication [81].

\section{Diabetes and adiponectin}

Adiponectin is considered to be the potent biomarker of Type 2 diabetes mellitus [82]. Jee et al. [83] and Tan et al. [84] demonstrated the negative relation of adiponectin with diabetes prevalence and the risk of prediabetic to develop diabetes. In addition, marker of glycemic control, also called glycated hemoglobin, correlated inversely with adiponectin [85]. Complications of the diabetes are also shown to be associated with adiponectin. It is involved in pathogenesis of diabetic retinopathy, one of the major causes of blindness [86]. Lower level has been detected in the diabetic patients with retinopathy than those without it [86]. Further similar level of adiponectin was observed in normoalbuminuric and microalbuminuric patients, whereas the concentration was high in diabetic patients having macroalbuminuria [87]. Lin et al. in their study including 733 diabetic patients observed that serum adiponectin is inversely correlated with the presence of renal dysfunction [88]. In diabetic patients, there is increased the risk of cardiovascular complication as the level of adiponectin decreases [89]. According to Gligor et al., adiponectin protects myocardium by increasing the level of cardioprotective agent high-density lipoprotein (HDL) cholesterol [90].

Researches have shown that one of the mechanisms, by which drugs used for the treatment of diabetics acts, is by increasing adiponectin levels [91] suggesting that adiponectin might be used as a novel therapeutic regimen for insulin resistance and Type 2 diabetes.

\section{Adiponectin and cardiovascular diseases}

Several studies have supported the roles of low adiponectin in the development of vascular disease [92]. Inverse relation of adiponectin with carotid intimal thickening [33], myocardial infarction [93], and essential hypertension [94] has been observed. Factors that determine the cardiovascular disorder risk such as serum cholesterol and triglycerides were negatively correlated, whereas HDL was positively correlated with adiponectin [29].

As stated in previous studies, adiponectin protects ischemic myocardium by suppressing the activity of NADH oxidase and inducible 
NOS [95]. Adiponectin also correlates positively with progenitor cells involved in vascular repair [96]. It modulates angiotensin II action in hypertension and renders protective effect [97]. Kumada et al. linked hypoadiponectinemia independently with coronary artery disease in men [98].

Although cardioprotective in action, increased adiponectin is a risk factor of heart failure and cardiovascular mortality [99], especially in cachexic patients [100]. The causative factor may be adiponectin resistance or increased production of brain natriuretic peptide, a vascular disease marker [101]. Some studies, such as those of Lindsay et al. [102], Lawlor et al. [103], and Sattar et al. [104], could not obtain any association between adiponectin levels and cardiovascular disease status. Therefore, the role of adiponectin in coronary artery disease development remains controversial, and the possible reason for the anomaly may be that the heart disease causes decreased adiponectin clearance by affecting kidney function thereby conflicting the analysis.

\section{Adiponectin and inflammation}

Increased levels of serum adiponectin have been found in the inflammatory disorders such as systemic lupus erythematosus [105] cystic fibrosis [106], inflammatory bowel disease [107], and rheumatoid arthritis [108]. Anti-inflammatory effects of adiponectin are rendered by direct action on inflammatory cells [109], suppression of NF- $\kappa \beta$ [52], inhibition of TNF- $\alpha$ [110], C-reactive protein (CRP) [111] and IL-8 [112] production. Further, it binds with C1q induces classical complement system and facilitates apoptotic cell clearance [113]. Venkatesh et al. have shown an inverse association between CRP and adiponectin levels [114] similar to that of Engeli et al., who also found a significant inverse correlation of adiponectin with the inflammatory mediators such as CRP and IL-6 [115].

\section{Adiponectin and malignancies}

Obesity-related malignancies can develop at different sites of the body such as endometrium, breast colon, stomach, and prostate; all of which are negatively associated with adiponectin [116]. It may be either due to the indirect effects of adiponectin through hormonal and cytokine level modifications or due to direct effects through inhibition of mitogenic growth factors related to cell proliferation [117]. A metaanalysis research of Wei et al., on the association of adiponectin with the development of cancer, indicated that the circulating adiponectin was lower in the patients with various cancers [118]. Study of Kang et al. revealed that the breast cancer patients with lower median adiponectin are more prone to lymph node metastasis [119].

The risk of endometrial cancer in women having high BMI and low adiponectin level increases nearly by 6 -folds [120]. Men with the highest adiponectin concentration have almost $60 \%$ reduced the risk of colorectal cancer [121] and nearly $70 \%$ reduced the risk of developing prostate cancer [122]. Small case-control study has shown a negative association of renal carcinoma [123] and acute myeloblastic leukemia with adiponectin [116] supporting the fact that adiponectin treatment suppresses myelomonocyte cell proliferation [110].

\section{Adiponectin and other disorders}

Studies have established role of adiponectin in other peripheral tissues such as lungs, liver, and kidney disorders too. A recent study on mice with genetic deficiency of adiponectin demonstrated increased systemic and local inflammation, alveolar simplification, and enlargement due to abnormal postnatal alveolar development [55]. These defects in such mice were attenuated by adenoviral adiponectin therapy [124] Decreased serum adiponectin correlated with poor asthmatic lung function and chronic obstructive pulmonary disease [125].

In hepatocytes, lower adiponectin level is seen hepatic steatosis [126] fatty liver and injuries [127]. Due to insulin resistance, there is increased lipolysis in adipocytes but increased lipogenesis in hepatocytes causing accumulation of lipid [128]. However, increased levels of adiponectin have been detected in liver cirrhosis. Possible reasons may be decreased hepatic clearance or compensation to excess production of proinflammatory cytokines [34]. Available researches indicated adiponectin to be renoprotective [129]. It protects the kidney from progression toward fibrosis and hypertrophy [130]. Doumatey et al. observed an inverse relationship of adiponectin with estimated glomerular filtration rate (GFR) [131], whereas Kawamoto et al. found a positive association of HMW adiponectin with GFR [132]. Several studies have reported a significant excretion of adiponectin in the urine of patients with various renal diseases, whereas the question is still unanswered that whether adiponectin is synthesized within nephron itself or simply filtered by glomerulus [133].

\section{CONCLUSION}

The purpose of this review is not to requote whatever has been done in earlier investigations but is to help the researchers who are investigating the utility of adiponectin in different sectors of health. The pathophysiology of various inflammatory diseases, cancer, and disorders related to kidney, lung, liver, and their association with adiponectin remain unclear. This review may be worthful for the researchers to elucidate such unclear facts and the related mechanism behind this. In conclusion, among the various adipokines, adiponectin is the abundant protein produced by adipose tissue. It plays an important role in carbohydrate and lipid metabolism in various tissues. It has been found to be associated with various disorders such as diabetes mellitus, atherosclerosis, inflammations, cancers, renal, and pulmonary disorders. Further investigations including large sample size are required to unveil in depth the clinical roles of adiponectin so that it can be used as a potent therapeutic regimen for the management of associated disorders in future.

\section{REFERENCES}

1. Galic S, Oakhill JS, Steinberg GR. Adipose tissue as an endocrine organ. Mol Cell Endocrinol 2010;316(2):129-39.

2. Peterlin BL, Alexander G, Tabby D, Reichenberger E. Oligomerization state-dependent elevations of adiponectin in chronic daily headache. Neurology 2008;70(20):1905-11.

3. Turer AT, Scherer PE. Adiponectin: Mechanistic insights and clinical implications. Diabetologia 2012;55(9):2319-26.

4. Hu E, Liang P, Spiegelman BM. AdipoQ is a novel adipose-specific gene dysregulated in obesity. J Biol Chem 1996;271(18):10697-703.

5. Scherer PE, Williams S, Fogliano M, Baldini G, Lodish HF. A novel serum protein similar to $\mathrm{C} 1 \mathrm{q}$, produced exclusively in adipocytes. J Biol Chem 1995;270(45):26746-9.

6. Berg AH, Combs TP, Du X, Brownlee M, Scherer PE. The adipocytesecreted protein Acrp30 enhances hepatic insulin action. Nat Med 2001;7(8):947-53.

7. Tabata M, Kadomatsu T, Fukuhara S, Miyata K, Ito Y, Endo M, et al. Angiopoietin-like protein 2 promotes chronic adipose tissue inflammation and obesity-related systemic insulin resistance. Cell Metab 2009;10(3):178-88.

8. Fujimatsu D, Kotooka N, Inoue T, Nishiyama M, Node K. Association between high molecular weight adiponectin levels and metabolic parameters. J Atheroscler Thromb 2009;16:553-9.

9. Kadowaki T, Yamauchi T, Kubota N, Hara K, Ueki K, Tobe K. Adiponectin and adiponectin receptors in insulin resistance, diabetes, and the metabolic syndrome. J Clin Invest 2006;116(7):1784-92.

10. Yamauchi T, Nio Y, Maki T, Kobayashi M, Takazawa T, Iwabu M, et al. Targeted disruption of AdipoR1 and AdipoR2 causes abrogation of adiponectin binding and metabolic actions. Nat Med 2007;13(3):332-9.

11. Hug C, Wang J, Ahmad NS, Bogan JS, Tsao TS, Lodish HF T-cadherin is a receptor for hexameric and high-molecularweight forms of Acrp30/adiponectin. Proc Natl Acad Sci U S A 2004;101(28):10308-13

12. Awazawa M, Ueki K, Inabe K, Yamauchi T, Kubota N, Kaneko K, et al. Adiponectin enhances insulin sensitivity by increasing hepatic IRS-2 expression via a macrophage-derived IL-6-dependent pathway. Cell Metab 2011;13(4):401-12.

13. Lara-Castro C, Fu Y, Chung BH, Garvey WT. Adiponectin and the metabolic syndrome: Mechanisms mediating risk for metabolic and cardiovascular disease. Curr Opin Lipidol 2007;18(3):263-70.

14. Jortay J, Senou M, Delaigle A, Noel L, Funahashi T, Maeda N, et al. 
Local induction of adiponectin reduces lipopolysaccharide-triggered skeletal muscle damage. Endocrinology 2010;151:4840-51.

15. Pedersen BK, Febbraio MA. Muscle as an endocrine organ: Focus on muscle-derived interleukin-6. Physiol Rev 2008;88(4):1379-406.

16. Yamauchi T, Kamon J, Waki H, Terauchi Y, Kubota N, Hara K, et al. The fat-derived hormone adiponectin reverses insulin resistance associated with both lipoatrophy and obesity. Nat Med 2001;7(8):941-6.

17. Yoon MJ, Lee GY, Chung JJ, Ahn YH, Hong SH, Kim JB. Adiponectin increases fatty acid oxidation in skeletal muscle cells by sequential activation of AMP-activated protein kinase, p38 mitogen-activated protein kinase, and peroxisome proliferator-activated receptor alpha. Diabetes 2006;55(9):2562-70.

18. Lee B, Shaon J. Adiponectin and lipid metabolism in skeletal muscle. Acta Pharm Sin B 2012;2(4):335-40.

19. Høeg LD, Sjøberg KA, Lundsgaard AM, Jordy AB, Hiscock N, Wojtaszewski JF, et al. Adiponectin concentration is associated with muscle insulin sensitivity, AMPK phosphorylation, and ceramide content in skeletal muscles of men but not women. J Appl Physiol 2013;114(5):592-601.

20. Ceddia RB, Somwar R, Maida A, Fang X, Bikopoulos G, Sweeney G. Globular adiponectin increases GLUT4 translocation and glucose uptake but reduces glycogen synthesis in rat skeletal muscle cells. Diabetologia 2005;48(1):132-9.

21. Qiao L, Kinney B, Yoo HS, Lee B, Schaack J, Shao J. Adiponectin increases skeletal muscle mitochondrial biogenesis by suppressing mitogen-activated protein kinase phosphatase-1. Diabetes 2012;61(6):1463-70.

22. Tomas E, Tsao TS, Saha AK, Murrey HE, Zhang CC, Itani SI, et al. Enhanced muscle fat oxidation and glucose transport by ACRP30 globular domain: Acetyl-CoA carboxylase inhibition and AMPactivated protein kinase activation. Proc Natl Acad Sci U S A 2002;99(25):16309-13

23. Roepstorff C, Halberg N, Hillig T, Saha AK, Ruderman NB, Wojtaszewski JF, et al. Malonyl-CoA and carnitine in regulation of fat oxidation in human skeletal muscle during exercise. Am J Physiol Endocrinol Metab 2005;288(1):E133-42.

24. Mead JR, Irvine SA, Ramji DP. Lipoprotein lipase: Structure, function, regulation, and role in disease. J Mol Med (Berl) 2002;80(12):753-69.

25. De Vries R, Wolffenbuttel BH, Sluiter WJ, van Tol A, Dullaart RP. Post-heparin plasma lipoprotein lipase, but not hepatic lipase activity, is related to plasma adiponectin in type 2 diabetic patients and healthy subjects. Clin Lab 2005;51(7-8):403-9.

26. Stefan N, Vozarova B, Funahashi T, Matsuzawa Y, Weyer C, Lindsay RS, et al. Plasma adiponectin concentration is associated with skeletal muscle insulin receptor tyrosine phosphorylation, and low plasma concentration precedes a decrease in whole-body insulin sensitivity in humans. Diabetes 2002;51:1884-8.

27. Mullen KL, Pritchard J, Ritchie I, Snook LA, Chabowski A, Bonen A, et al. Adiponectin resistance precedes the accumulation of skeletal muscle lipids and insulin resistance in high-fat-fed rats. Am J Physiol Regul Integr Comp Physiol 2009;296(2):R243-51.

28. Summers SA. Ceramides in insulin resistance and lipotoxicity. Prog Lipid Res 2006;45(1):42-72.

29. Civitarese AE, Ukropcova B, Carling S, Hulver M, DeFronzo RA, Mandarino L, et al. Role of adiponectin in human skeletal muscle bioenergetics. Cell Metab 2006;4(1):75-87.

30. von Eynatten M, Schneider JG, Humpert PM, Rudofsky G, Schmidt N, Barosch $\mathrm{P}$, et al. Decreased plasma lipoprotein lipase in hypoadiponectinemia: An association independent of systemic inflammation and insulin resistance. Diabetes Care 2004;27(12):2925-9.

31. Shimano M, Ouchi N, Shibata R, Ohashi K, Pimentel DR, Murohara T, et al. Adiponectin deficiency exacerbates cardiac dysfunction following pressure overload through disruption of an AMPKdependent angiogenic response. J Mol Cell Cardiol 2010;49(2):210-20.

32. Arita Y, Kihara S, Ouchi N, Maeda K, Kuriyama H, Okamoto Y, et al. Adipocyte-derived plasma protein adiponectin acts as a plateletderived growth factor-BB-binding protein and regulates growth factorinduced common postreceptor signal in vascular smooth muscle cell. Circulation 2002;105(24):2893-8.

33. Kiris I, Tekin I, Yesildag A, Vural H, Oyar O, Sirin B, et al. Inverse relationship between adiponectin levels and subclinical carotid atherosclerosis in patients undergoing coronary artery bypass grafting. Int Heart J 2006;47(6):855-66.

34. Dadson K, Liu Y, Sweeney G. Adiponectin action: A combination of endocrine and autocrine/paracrine effects. Front Endocrinol (Lausanne) 2011;2(62):62.
35. Kato H, Kashiwagi H, Shiraga M, Tadokoro S, Kamae T, Ujiie H, et al. Adiponectin acts as an endogenous antithrombotic factor. Arterioscler Thromb Vasc Biol 2006;26(1):224-30.

36. Shibata R, Sato K, Pimentel DR, Takemura Y, Kihara S, Ohashi K, et al. Adiponectin protects against myocardial ischemia-reperfusion injury through AMPK- and COX-2-dependent mechanisms. Nat Med 2005;11(10):1096-103

37. Mariman EC, Wang P. Adipocyte extracellular matrix composition, dynamics and role in obesity. Cell Mol Life Sci 2010;67(8):1277-92.

38. Kobashi C, Urakaze M, Kishida M, Kibayashi E, Kobayashi H, Kihara S, et al. Adiponectin inhibits endothelial synthesis of interleukin-8. Circ Res 2005;97(12):1245-52.

39. Furukawa K, Hori M, Ouchi N, Kihara S, Funahashi T, Matsuzawa Y, et al. Adiponectin down-regulates acyl-coenzyme A: Cholesterol acyltransferase-1 in cultured human monocyte-derived macrophages. Biochem Biophys Res Commun 2004;317(3):831-6.

40. Kumada M, Kihara S, Ouchi N, Kobayashi H, Okamoto Y, Ohashi $\mathrm{K}$, et al. Adiponectin specifically increased tissue inhibitor of metalloproteinase- 1 through interleukin-10 expression in human macrophages. Circulation 2004;109(17):2046-9.

41. Wagner DD, Burger PC. Platelets in inflammation and thrombosis. Arterioscler Thromb Vasc Biol 2003;23(12):2131-7.

42. Lee S, Kwak HB. Role of adiponectin in metabolic and cardiovascular disease. J Exerc Rehabil 2014;10(2):54-9.

43. Wang ZV, Scherer PE. Adiponectin, cardiovascular function, and hypertension. Hypertension 2008;51(1):8-14

44. Cheng KK, Lam KS, Wang Y, Huang Y, Carling D, Wu D, et al. Adiponectin-induced endothelial nitric oxide synthase activation and nitric oxide production are mediated by APPL1 in endothelial cells. Diabetes 2007;56(5):1387-94.

45. Fang X, Palanivel R, Cresser J, Schram K, Ganguly R, Thong FS, et al. An APPL1-AMPK signaling axis mediates beneficial metabolic effects of adiponectin in the heart. Am J Physiol Endocrinol Metab 2010;299(5):E721-9.

46. Shklyaev S, Aslanidi G, Tennant M, Prima V, Kohlbrenner E, Kroutov V, et al. Sustained peripheral expression of transgene adiponectin offsets the development of diet-induced obesity in rats. Proc Natl Acad Sci U S A 2003;100(24):14217-22.

47. Kadowaki T, Yamauchi T, Kubota N. The physiological and pathophysiological role of adiponectin and adiponectin receptors in the peripheral tissues and CNS. FEBS Lett 2008;582(1):74-80.

48. Wang Y, Zhou M, Lam KS, Xu A. Protective roles of adiponectin in obesity-related fatty liver diseases: Mechanisms and therapeutic implications. Arq Bras Endocrinol Metabol 2009;53(2):201-12.

49. Caligiuri A, Bertolani C, Guerra CT, Aleffi S, Galastri S, Trappoliere $\mathrm{M}$, et al. Adenosine monophosphate-activated protein kinase modulates the activated phenotype of hepatic stellate cells. Hepatology 2008;47:668-76.

50. Bertolani C, Marra F. The role of adipokines in liver fibrosis Pathophysiology 2008;15(2):91-101.

51. Sennello JA, Fayad R, Morris AM, Eckel RH, Asilmaz E, Montez J, et al. Regulation of T cell-mediated hepatic inflammation by adiponectin and leptin. Endocrinology 2005;146(5):2157-64

52. Yamaguchi N, Argueta JG, Masuhiro Y, Kagishita M, Nonaka K, Saito T, et al. Adiponectin inhibits Toll-like receptor family-induced signaling. FEBS Lett 2005;579(30):6821-6.

53. Nigro E, Scudiero O, Sarnataro D, Mazzarella G, Sofia M, Bianco A, et al. Adiponectin affects lung epithelial A549 cell viability counteracting $\mathrm{TNFa}$ and IL-1ß toxicity through AdipoR1. Int J Biochem Cell Biol 2013;45(6):1145-53.

54. Jun ZJ, Ming SY, Jing W, Zhao QF, Ping T, Lei Y. Elevated circulating plasma adiponectin in normal weight male patients with stable chronic obstructive pulmonary disease (COPD). Int J Med Sci 2012;2(12):296-300.

55. Thyagarajan B, Jacobs DR Jr, Smith LJ, Kalhan R, Gross MD, Sood A. Serum adiponectin is positively associated with lung function in young adults, independent of obesity: The CARDIA study. Respir Res 2010;11:176.

56. Ohashi K, Ouchi N, Sato K, Higuchi A, Ishikawa TO, Herschman HR, et al. Adiponectin promotes revascularization of ischemic muscle through a cyclooxygenase 2-dependent mechanism. Mol Cell Biol 2009;29:3487-99.

57. Matsumoto H, Tamura S, Kamada Y, Kiso S, Fukushima J, Wada A, et al. Adiponectin deficiency exacerbates lipopolysaccharid e/D-galactosamine-induced liver injury in mice. World J Gastroenterol 2006;12(21):3352-8.

58. Summer R, Fiack CA, Ikeda Y, Sato K, Dwyer D, Ouchi N, et al. 
Adiponectin deficiency: A model of pulmonary hypertension associated with pulmonary vascular disease. Am J Physiol Lung Cell Mol Physiol 2009;297(3):L432-8.

59. Oh J, Rabb H. Adiponectin: An enlarging role in acute kidney injury. Kidney Int 2013;83(4):546-8.

60. Shen YY, Hughes JT, Charlesworth JA, Kelly JJ, Peake PW. Adiponectin is present in the urine in its native conformation, and specifically reduces the secretion of MCP-1 by proximal tubular cells Nephrology (Carlton) 2008;13(5):405-10.

61. Fang F, Liu GC, Kim C, Yassa R, Zhou J, Scholey JW. Adiponectin attenuates angiotensin II-induced oxidative stress in renal tubular cells through AMPK and cAMP-Epac signal transduction pathways. Am J Physiol Renal Physiol 2013;304(11):F1366-74

62. Rutkowski JM, Wang ZV, Park AS, Zhang J, Zhang D, Hu MC, et al Adiponectin promotes functional recovery after podocyte ablation. J Am Soc Nephrol 2013;24(2):268-82.

63. Nakamaki S, Satoh H, Kudoh A, Hayashi Y, Hirai H, Watanabe T. Adiponectin reduces proteinuria in streptozotocin-induced diabetic Wistar rats. Exp Biol Med (Maywood) 2011;236(5):614-20

64. Tacke F, Wüstefeld T, Horn R, Luedde T, Srinivas Rao A, Manns MP, et al. High adiponectin in chronic liver disease and cholestasis suggests biliary route of adiponectin excretion in vivo. J Hepatol 2005;42(5):666-73.

65. Koshimura J, Fujita H, Narita T, Shimotomai T, Hosoba M, Yoshioka $\mathrm{N}$, et al. Urinary adiponectin excretion is increased in patients with overt diabetic nephropathy. Biochem Biophys Res Commun 2004;316(1):165-9.

66. Shimotomai T, Kakei M, Narita T, Koshimura J, Hosoba M, Kato M, et al. Enhanced urinary adiponectin excretion in IgA-nephropathy patients with proteinuria. Ren Fail 2005;27(3):323-8.

67. Spranger J, Verma S, Göhring I, Bobbert T, Seifert J, Sindler AL et al. Adiponectin does not cross the blood-brain barrier but modifies cytokine expression of brain endothelial cells. Diabetes 2006;55(1):141-7.

68. Psilopanagioti A, Papadaki H, Kranioti EF, Alexandrides TK, Varakis JN. Expression of adiponectin and adiponectin receptors in human pituitary gland and brain. Neuroendocrinology 2009;89(1):38-47

69. Kubota N, Yano W, Kubota T, Yamauchi T, Itoh S, Kumagai H, et al. Adiponectin stimulates AMP-activated protein kinase in the hypothalamus and increases food intake. Cell Metab 2007;6(1):55-68.

70. Combs TP, Berg AH, Rajala MW, Klebanov S, Iyengar P, Jimenez CJ, et al. Sexual differentiation, pregnancy, calorie restriction, and aging affect the adipocyte-specific secretory protein adiponectin. Diabetes 2003;52(2):268-76

71. Xu A, Chan KW, Hoo RL, Wang Y, Tan KC, Zhang J, et al Testosterone selectively reduces the high molecular weight form of adiponectin by inhibiting its secretion from adipocytes. J Biol Chem 2005;280(18):18073-80

72. Böttner A, Kratzsch J, Müller G, Kapellen TM, Blüher S, Keller E, et al. Gender differences of adiponectin levels develop during the progression of puberty and are related to serum androgen levels. J Clin Endocrinol Metab 2004;89(8):4053-61.

73. Balsan GA, Vieira JL, Oliveira AM, Portal VL. Relationship between adiponectin, obesity and insulin resistance. Rev Assoc Med Bras 2015;61(1):72-80

74. Arita Y, Kihara S, Ouchi N, Takahashi M, Maeda K, Miyagawa J, et al. Paradoxical decrease of an adipose-specific protein, adiponectin, in obesity. Biochem Biophys Res Commun 1999;257(1):79-83.

75. Ryo M, Nakamura T, Kihara S, Kumada M, Shibazaki S, Takahashi M, et al. Adiponectin as a biomarker of the metabolic syndrome. Circ J 2004;68(11):975-81.

76. Eizadi M, Khorshidi D, Doali H. Relationship between serum adiponectin with anthropometrical and lipid profile biochemical indexes in obese adult men. IPCBEE 2011;16:70-3.

77. Ouchi N, Kihara S, Funahashi T, Matsuzawa Y, Walsh K. Obesity, adiponectin and vascular inflammatory disease. Curr Opin Lipidol 2003;14(6):561-6

78. Haluzík M, Parízková J, Haluzík MM. Adiponectin and its role in the obesity-induced insulin resistance and related complications. Physiol Res 2004;53(2):123-9.

79. Kojima S, Funahashi T, Sakamoto T, Miyamoto S, Soejima H, Hokamaki $\mathrm{J}$, et al. The variation of plasma concentrations of a novel, adipocyte derived protein, adiponectin, in patients with acute myocardial infarction. Heart 2003;89(6):667.

80. Hoffstedt J, Arvidsson E, Sjölin E, Wåhlén K, Arner P. Adipose tissue adiponectin production and adiponectin serum concentration in human obesity and insulin resistance. J Clin Endocrinol Metab 2004;89(3):1391-6.

81. Zaki ME, Salam MA, Hassan NA, Mohamed SK, Zaher MM, Ibraheim RA, et al. Association of adiponectin gene polymorphisms $276 \mathrm{~g}>\mathrm{t}$ with obesity and biochemical parameters in adolescents. Int J Pharm Pharm Sci 2014;6(5)226-9.

82. Lindsay RS, Funahashi T, Hanson RL, Matsuzawa Y, Tanaka S, Tataranni PA, et al. Adiponectin and development of type 2 diabetes in the Pima Indian population. Lancet 2002;360(9326):57-8.

83. Jee SH, Ahn CW, Park JS, Park CG, Kim HS, Lee SH, et al. Serum adiponectin and type 2 diabetes: A 6-year follow-up cohort study. Diabetes Metab J 2013;37(4):252-61.

84. Tan CF, Dakis MK, Reyes CL, Ki DY, Langcamon SJ, Magdamit DT, et al. Adiponectin as a biomarker of type 2 diabetes mellitus. Int $\mathrm{J} \mathrm{Sc}$ Res Public 2015;5(7):1-4.

85. Goodarzi MT, Babaahmadi-Rezaei H, Kadkhodaei-Eliaderani M Haddadinezhad S. Relationship of serum adiponectin with blood lipids, $\mathrm{HbA}(1) \mathrm{c}$, and hs-CRP in type II diabetic postmenopausal women. J Clin Lab Anal 2007;21:197-200.

86. Yilmaz MI, Sonmez A, Acikel C, Celik T, Bingol N, Pinar M, et al. Adiponectin may play a part in the pathogenesis of diabetic retinopathy. Eur J Endocrinol 2004;151(1):135-40.

87. Saraheimo M, Forsblom C, Thorn L, Wadén J, Rosengård-Bärlund M, Heikkilä $\mathrm{O}$, et al. Serum adiponectin and progression of diabetic nephropathy in patients with type 1 diabetes. Diabetes Care 2008;31(6):1165-9.

88. Lin J, Hu FB, Curhan G. Serum adiponectin and renal dysfunction in men with type 2 diabetes. Diabetes Care 2007;30(2):239-44.

89. Elokely A, Shoukry A, Ghonemy TA, Atia M. Association between low adiponectin level and cardiovascular complications in diabetic and non diabetic patients with end stage renal disease. Arab J Nephrol Transplant 2010;3(3):15-21.

90. Gligor R, Puschita M, Zdremtan D, Crisnic I. Relationship between adiponectin and certain metabolic parameters in diabetic and cardiovascular disease patients. Proc Rom Acad 2012;14:B101-7.

91. Tao L, Wang Y, Gao E, Zhang H, Yuan Y, Lau WB, et al. Adiponectin An indispensable molecule in rosiglitazone cardioprotection following myocardial infarction. Circ Res 2010;106:409-17.

92. Lam KS, Xu A. Adiponectin: Protection of the endothelium. Curr Diab Rep 2005;5(4):254-9.

93. Pischon T, Girman CJ, Hotamisligil GS, Rifai N, Hu FB, Rimm EB. Plasma adiponectin levels and risk of myocardial infarction in men. JAMA 2004;291(14):1730-7

94. Ouchi N, Ohishi M, Kihara S, Funahashi T, Nakamura T, Nagaretani $\mathrm{H}$, et al. Association of hypoadiponectinemia with impaired vasoreactivity. Hypertension 2003;42(3):231-4.

95. Tao L, Gao E, Jiao X, Yuan Y, Li S, Christopher TA, et al. Adiponectin cardioprotection after myocardial ischemia/reperfusion involves the reduction of oxidative/nitrative stress. Circulation 2007;115(11):1408-16.

96. Nilsson PM, Engström G, Hedblad B, Frystyk J, Persson MM Berglund $\mathrm{G}$, et al. Plasma adiponectin levels in relation to carotid intima media thickness and markers of insulin resistance. Arterioscler Thromb Vasc Biol 2006;26(12):2758-62.

97. Furuhashi M, Ura N, Higashiura K, Murakami H, Tanaka M, Moniwa $\mathrm{N}$, et al. Blockade of the renin-angiotensin system increases adiponectin concentrations in patients with essential hypertension. Hypertension 2003;42(1):76-81.

98. Kumada M, Kihara S, Sumitsuji S, Kawamoto T, Matsumoto S, Ouchi N, et al. Association of hypoadiponectinemia with coronary artery disease in men. Arterioscler Thromb Vasc Biol 2003;23(1):85-9.

99. Wannamethee SG, Whincup PH, Lennon L, Sattar N. Circulating adiponectin levels and mortality in elderly men with and without cardiovascular disease and heart failure. Arch Intern Med 2007;167(14):1510-7.

100. McEntegart MB, Awede B, Petrie MC, Sattar N, Dunn FG, MacFarlane NG, et al. Increase in serum adiponectin concentration in patients with heart failure and cachexia: Relationship with leptin, other cytokines, and B-type natriuretic peptide. Eur Heart 2007;28(7):829-35.

101. Wannamethee SG, Welsh P, Whincup PH, Sawar N, Thomas MC Gudnarsson V, et al. High adiponectin and increased risk of cardiovascular disease and mortality in asymptomatic older men Does NT-proBNP help to explain this association? Eur J Cardiovasc Prev Rehabil 2011;18(1):65-71.

102. Lindsay RS, Resnick HE, Zhu J, Tun ML, Howard BV, Zhang Y, et al. Adiponectin and coronary heart disease: The Strong Heart Study. 
Arterioscler Thromb Vasc Biol 2005;25(3):e15-6.

103. Lawlor DA, Davey Smith G, Ebrahim S, Thompson C, Sattar N Plasma adiponectin levels are associated with insulin resistance, but do not predict future risk of coronary heart disease in women. J Clin Endocrinol Metab 2005;90(10):5677-83.

104. Sattar N, Wannamethee G, Sarwar N, Tchernova J, Cherry L, Wallace AM, et al. Adiponectin and coronary heart disease: A prospective study and meta-analysis. Circulation 2006;114(7):623-9.

105. Rovin BH, Song H, Hebert LA, Nadasdy T, Nadasdy G, Birmingham DJ, et al. Plasma, urine, and renal expression of adiponectin in human systemic lupus erythematosus. Kidney Int 2005;68(4):1825-33.

106. Moriconi N, Kraenzlin M, Müller B, Keller U, Nusbaumer CP, Stöhr S, et al. Body composition and adiponectin serum concentrations in adult patients with cystic fibrosis. J Clin Endocrinol Metab 2006;91(4):1586-90.

107. Karmiris K, Koutroubakis IE, Xidakis C, Polychronaki M, Voudouri T, Kouroumalis EA. Circulating levels of leptin, adiponectin, resistin, and ghrelin in inflammatory bowel disease. Inflamm Bowel Dis 2006;12(2):100-5.

108. Otero M, Lago R, Gomez R, Lago F, Dieguez C, Gómez-Reino JJ, et al. Changes in plasma levels of fat-derived hormones adiponectin, leptin, resistin and visfatin in patients with rheumatoid arthritis. Ann Rheum Dis 2006;65(9):1198-201.

109. Robinson K, Prins J, Venkatesh B. Clinical review: Adiponectin biology and its role in inflammation and critical illness. Crit Care 2011;15(2):221

110. Yokota T, Oritani K, Takahashi I, Ishikawa J, Matsuyama A, Ouchi $\mathrm{N}$, et al. Adiponectin, a new member of the family of soluble defense collagens, negatively regulates the growth of myelomonocytic progenitors and the functions of macrophages. Blood 2000;96(5):1723-32.

111. Wulster-Radcliffe MC, Ajuwon KM, Wang J, Christian JA, Spurlock ME. Adiponectin differentially regulates cytokines in porcine macrophages. Biochem Biophys Res Commun 2004;316(3):924-9.

112. Choi KM, Ryu OH, Lee KW, Kim HY, Seo JA, Kim SG, et al. Serum adiponectin, interleukin-10 levels and inflammatory markers in the metabolic syndrome. Diabetes Res Clin Pract 2007;75(2):235-40.

113. Chen H, Montagnani M, Funahashi T, Shimomura I, Quon MJ. Adiponectin stimulates production of nitric oxide in vascular endothelial cells. J Biol Chem 2003;278(45):45021-6.

114. Venkatesh B, Hickman I, Nisbet J, Cohen J, Prins J. Changes in serum adiponectin concentrations in critical illness: A preliminary investigation. Crit Care 2009;13(4):R105.

115. Engeli S, Feldpausch M, Gorzelniak K, Hartwig F, Heintze U, Janke J, et al. Association between adiponectin and mediators of inflammation in obese women. Diabetes 2003;52(4):942-7.

116. Petridou E, Mantzoros CS, Dessypris N, Dikalioti SK, Trichopoulos D. Adiponectin in relation to childhood myeloblastic leukaemia. Br J Cancer 2006;94(1):156-60

117. Wang Y, Lam KS, Xu JY, Lu G, Xu LY, Cooper GJ, et al. Adiponectin inhibits cell proliferation by interacting with several growth factors in an oligomerization-dependent manner. J Biol Chem 2005;280(18):18341-7.

118. Wei T, Ye P, Peng X, Wu LL, Yu GY. Circulating adiponectin levels in various malignancies: An updated meta-analysis of 107 studies. Oncotarget 2016.

119. Kang JH, Yu BY, Youn DS. Relationship of serum adiponectin and resistin levels with breast cancer risk. J Korean Med Sci 2007;22(1):117-21.

120. Dal Maso L, Augustin LS, Karalis A, Talamini R, Franceschi S, Trichopoulos D, et al. Circulating adiponectin and endometrial cancer risk. J Clin Endocrinol Metab 2004;89(3):1160-3.

121. Wei EK, Giovannucci E, Fuchs CS, Willett WC, Mantzoros CS. Low plasma adiponectin levels and risk of colorectal cancer in men: A prospective study. J Natl Cancer Inst 2005;97(22):1688-94

122. Barb D, Williams CJ, Neuwirth AK, Mantzoros CS. Adiponectin in relation to malignancies: A review of existing basic research and clinical evidence. Am J Clin Nutr 2007;86:s858-66.

123. Spyridopoulos TN, Petridou ET, Skalkidou A, Dessypris N, Chrousos GP, Mantzoros CS; Obesity and Cancer Oncology Group. Low adiponectin levels are associated with renal cell carcinoma: A case-control study. Int J Cancer 2007;120(7):1573-8.

124. Nakanishi K, Takeda Y, Tetsumoto S, Iwasaki T, Tsujino K, Kuhara H, et al. Involvement of endothelial apoptosis underlying chronic obstructive pulmonary disease-like phenotype in adiponectinnull mice: Implications for therapy. Am J Respir Crit Care Med 2011;183(9):1164-75.

125. Sood A, Cui X, Qualls C, Beckett WS, Gross MD, Steffes MW, et al. Association between asthma and serum adiponectin concentration in women. Thorax 2008;63(10):877-82.

126. Buechler C, Wanninger J, Neumeier M. Adiponectin, a key adipokine in obesity related liver diseases. World J Gastroenterol 2011;17(23):2801-11.

127. Hui JM, Hodge A, Farrell GC, Kench JG, Kriketos A, George J. Beyond insulin resistance in NASH: TNF-alpha or adiponectin? Hepatology 2004;40(1):46-54.

128. Angulo P. Nonalcoholic fatty liver disease. N Engl J Med 2002;346(16):1221-31.

129. Abe Y, Eto S, Matsumae T, Ogahara S, Murata T, Watanabe M, et al. The proportion and metabolic effects of adiponectin multimeric isoforms in patients with chronic kidney disease on maintenance hemodialysis. Ren Fail 2010;32(7):849-54.

130. Ohashi K, Iwatani H, Kihara S, Nakagawa Y, Komura N, Fujita K, et al. Exacerbation of albuminuria and renal fibrosis in subtotal renal ablation model of adiponectin-knockout mice. Arterioscler Thromb Vasc Biol 2007;27(9):1910-7.

131. Doumatey AP, Zhou J, Huang H, Adeleye J, Balogun W, Fasanmade O, et al. Circulating adiponectin is associated with renal function independent of age and serum lipids in west africans. Int J Nephrol 2012;2012:730920.

132. Kawamoto R, Tabara Y, Kohara K, Miki T, Abe M, Kusunoki T, et al. Serum high molecular weight adiponectin is associated with mild renal dysfunction in Japanese adults. J Atheroscler Thromb 2010;17(11):1141-8

133. Fujita H, Morii T, Koshimura J, Ishikawa M, Kato M, Miura T, et al. Possible relationship between adiponectin and renal tubular injury in diabetic nephropathy. Endocr J 2006;53(6):745-52. 